\title{
The Influence of Mind Mapping Learning Model to the Fourth Graders Primary Students' Creativity
}

\author{
Sri Wahyuni \\ Universitas Negeri Surabaya \\ Surabaya, Indonesia \\ sriwahyunipepe69@gmail.com
}

\begin{abstract}
This study aims to describe the influence of mind mapping learning model to the fourth grade primary students' creativity. It was conducted in Kedungrejo Primary School at Waru, Sidoarjo participated by 48 students in Class IV-A and IV$B$ in academic year 2017/2018. The students were categorised into two groups namely, control and experiment class. This research used quantitative method focusing on experimental research with non-equivalent control group design. The researcher used observation checklist and creativity test as data instrument method to gain the data. Those data had been analysed by using Statistical Package for the Social Science (SPSS) version 17. All the creativity test questions had been examined through validity test using Product Moment Correlation and Reliability Test by Alpha Cronbach's, and the result was valid and reliable. There was a normality data test using Kolmogorov Smirnov, while Independent t-test was applied to test the homogeneity. As a result, the data were normally distributed and homogeneous. Three aspects that influence students' creativity are: students' competence, roles, and learning process and facilities or media that had been used. Almost $60 \%$ of facilities or media was appropriate with students' comprehension. It is because students experienced using mind mapping properly during teaching and learning process. Therefore, their experience influenced students' competence in improving their creativity. Finally, the result of the first hypothesis test showed that students' creativity in experiment class was better than in class control.
\end{abstract}

\section{Keywords—Mind Mapping, Creativity}

\section{INTRODUCTION}

Mind mapping is "all the thinking process in the brain with organising the linearity concepts which connects the branch of the concept itself and records the idea from all sources" [1]. Creativity is the ability to combine new knowledge identified from the smoothness, flexibility and originality of giving ideas and comprehended in improving and enriching ideas [2].

Currently, there are some studies conducted about "The implementation of mind mapping which can foster the fourth graders' primary students' creativity and understanding". Fauziah depicted through her study that mind mapping brought positive impact for students' creativity. However, there were some problems in students' understanding of the history of Islamic Kingdoms in Indonesia. Another study by Fadhilatul Fahmi discussed "The Influence of Mind Mapping Model to Creativity and Learning Result for Globalisation in
Indonesia". This study aimed to improve learning model using mind mapping. It was because, mind mapping was advantageous to foster students' creativity by organising ideas, creating diagrams, adding new information, memorising information, making the connection, comparing and arranging all information easily.

The result of the previous study revealed that students' ability was caused by the ineffective learning techniques. Students were not used to taking notes by themselves, so the knowledge was not stored properly. Therefore, this study aims to improve students' creativity in learning social subjects.

\section{RESEARCH METHOD}

The researcher applied experimental research, which was done strictly to examine cause and effect of variables [3]. Also, Nasir [4] stated that experiment is an observation which the researcher structured the condition, so it can be said that experimental research is a study which is conducted by manipulating the research object by using control. According to this two theories, it was concluded that experiment research was a study that tried to find the cause and effect of variables. One of the characters of experiment research was a treatment applied to the research object.

This study aimed to describe the influence of mind mapping learning model to students' creativity in social subjects using non-equivalent control group design. Sugiyono [5] stated that non-equivalent control group design is similar to pre-test and post-test control group design. However, non-equivalent control group design does not differentiate control group and experiment group, so they were not chosen randomly. Further, the control group was treated by lecture method, while mind-mapping model was applied to experiment group. The participants of this research were the fourth graders of primary students. It was located at Kedungrejo Primary School in Jalan Raya Waru number 39, Waru, Sidoarjo, East Java that took about the one-month observation on April 2018.

There were three stages of conducting this study according to Homan [as cited in 6]. First, preparation allowed the researcher to look for understanding about mind mapping learning model and creativity, knowing the condition of the samples before treatment, creating and testing instruments, choosing learning materials and 
designing a lesson plan. Second, implementation let the researcher chose the participants, set time to gather the data, and conducted pre-test, learning process with stimulus and post-test. The last, processing the data was analysing and processing the gained data and writing conclusion.

Furthermore, the variables of this study were categorised as a dependent and independent variable. The dependent variable was creativity while the independent variable was mind mapping learning model. Those variables were measured by using instrument based on the number of variables itself. Since the researcher had two variables, so there was two instruments to be applied according to Sugiyono [7]. They were an observation to know the process of mind mapping learning and test to examine students' creativity. Moreover, those two instruments had to be valid and reliable so that the researcher could collect the data easily, and the result could be more complete, systematic and easy to be processed [8].

According to Munandar [2], there are two components to test the creativity, namely aptitude traits (cognitive) and non-aptitude traits (affective). The researcher used a psychology scale consisting of seven ways. Then, the researcher created questions based on the indicator provided by the scale and consulted it to the validator to be validated. As it is believed that validity test is a measurement that shows the level of validity and reliability of an instrument [9]. Thus, to determine the indicator of the instruments, the sub-component was arranged based on the variable, then it was consulted to the validators, and the researcher created the score range. Correspondingly, the questions were created in two categories based on the rank of the scores, namely "positive" and "negative".

TABLE 1: SCORE-RANK IN CREATIVITY TEST

\begin{tabular}{|l|c|c|}
\hline \multirow{2}{*}{\multicolumn{1}{|c|}{ Answers }} & \multicolumn{2}{c|}{ Score } \\
\cline { 2 - 3 } & Negative & Positive \\
\hline Very Inappropriate & 5 & 1 \\
\hline Inappropriate & 4 & 2 \\
\hline Neutral & 3 & 3 \\
\hline Appropriate & 2 & 4 \\
\hline Very Appropriate & 1 & 5 \\
\hline
\end{tabular}

TABLE 2: EXAMPLE OF CREATIVITY TEST INSTRUMENT SCALE

\begin{tabular}{|c|l|c|c|c|c|c|}
\hline \multirow{2}{*}{ Statements } & \multicolumn{3}{|c|}{ Answers } \\
\cline { 3 - 7 } & \multicolumn{1}{|c|}{ VI } & I & N & A & VA \\
\hline 1. & $\begin{array}{l}\text { I like giving questions because it } \\
\text { makes me more understanding the } \\
\text { materials. }\end{array}$ & & & & & $\sqrt{ }$ \\
\hline
\end{tabular}

Information:

VI : Very Inappropriate

I : Inappropriate

$\mathrm{N} \quad$ : Neutral

A : Appropriate

\section{VA : Very Appropriate}

After creating 25 questions for those instrument scales, the researcher asked the validator to examine the validity and reliability for each question; then it was applied to the participants. In addition, there is a formula to count the coefficient of instrument reliability when the researcher used essay questions, called Cronbach Alpha. This formula is used to measure observation checklist, multiple choice questions and essay questions [10]. The coefficient result shows in table 3 [11]:

TABLE 3: CRITERIA OF INSTRUMENT RELIABILITY

\begin{tabular}{|l|l|}
\hline \multicolumn{1}{|c|}{ Reliability Criteria } & \multicolumn{1}{c|}{ Coefficient Interval } \\
\hline Very High & $0.80-1.000$ \\
\hline High & $0.60-0.799$ \\
\hline Adequate & $0.40-0.599$ \\
\hline Low & $0.20-0.399$ \\
\hline Very Low & $0.00-0.199$ \\
\hline
\end{tabular}

The researcher used SPSS 17 to analyse the data to investigate the influence of mind mapping learning model in improving primary students' creativity. Hence, the researcher used independent t-test as the statistical data analysis. The analysis started from (1) counting the average, (2) calculating the standard deviation, (3) test the normality data, (4) examine the homogeneity of two variables, and (5) test the hypotheses.

\section{FINDING AND DISCUSSION}

There were two groups in this study, the control group, which was treated using lecture method, and experiment group which was processed using mind mapping. The result showed that the significant result of those two group were 0.615 and 0.766 respectively. The p-value was $>.05$ meant that the students' creativity in each group was normally distributed. The homogeneity test, which valued 0.787 , described that the sample was homogeneous. Also, the F value was 0.073 while 0.787 was less than .05 meant that $\mathrm{H} 0$ was accepted, so those two groups were homogeneous. The independent $\mathrm{t}$-test resulted in significant value with 0.000 point, which was less than .05 . Then, the result of tcount consulted with ttable to test one side where ttable valued $1.684(\mathrm{~N}=40)$. Due to the result of tcount is bigger than ttable, it indicated that both samples were significantly different. Therefore, $\mathrm{H} 0$ was rejected, and $\mathrm{Ha}$ was accepted.

To sum up, students' creativity influenced by mind mapping learning model was higher than using lecture model. As Rousseau [as cited in 12] stated that in the process of learning, all the new knowledge is obtained by observation or experience. Ultimately, mind mapping learning model influenced students' creativity positively.

\section{IV.CONCLUSION}

The result showed that there was an influence of mind mapping learning model to the fourth grader students' creativity in social subjects. The influence of mind mapping learning model was higher than the lecture method based on 
the data analysis. Students were able to identify every single information then evaluate and conclude it systematically. In addition, students were able to share their opinion in a systematic structure compared to lecture method. Mind mapping learning model showed a positive result because students were given opportunities to interact with their peers in solving the problem. They were also able to develop the creativity through cooperating in creating mind maps from the lesson given in class.

\section{REFERENCES}

[1] T. Buzan, Mind Map: Untuk Meningkatkan Kreativitas. Jakarta: Gramedia Pustaka Utama, 2008.

[2] U. Munandar, Pengembangan Kreativitas Anak Berbakat. Jakarta: Rineka Cipta, 2004.

[3] A. Maksum, Metodologi Penelitian dalam Olahraga. Surabaya: Unesa University Press, 2012.
[4] M. Nasir, Metode Penelitian. Bogor: Ghalia Indonesia, 2013.

[5] Sugiyono, Metode Penelitian Kuantitatif, Kualitatif, dan $R \& D$ Bandung: Alfabeta, 2016.

[6] H. Usman and P. S. Akbar, Metodologi Penelitian Sosial. Jakarta: Bumi Aksara, 2016.

[7] Sugiyono, Metode Penelitian Kuantitatif, Kualitatif, dan $R \& D$ Bandung: Alfabeta, 2017.

[8] A. Suharsimi, Metodologi penelitian. Jakarta: Rineka Cipta, 2002.

[9] A. Suharsimi, Prosedur Penelitian Suatu Pendekatan Praktik Edisi Revisi. Jakarta: Rineka cipta, 2011.

[10] Suherman and Sukjaya, Evaluasi Pendidikan Matematika. Bandung: Wijayakusuma, 1990.

[11] Riduwan, Skala Pengukuran Variabel-Variabel Penelitian. Bandung: Alfabeta, 2008.

[12] A. M. Sardiman, Interaksi \& Motivasi Belajar Mengajar. Jakarta: Rajagrafindo Persada (Rajawali Pers), 2010. 